The information available on chemotherapy is fragmentary, though extensive, and fow generalizations are possible, and the book under notice suffers from fragmentation and compression. Since the first edition appeared, the discovery of the action of sulphonamide derivatives on bacterial infections has opened up great possibilities and caused the appearance of a spate of literature. A new chapter with more than 150 pages which is devoted to this absorbing topic contains an enormous amount of information and greatly enhances the usefulness of the book.

Books on chemotherapy are few, and this one will bo almost indispensablo to those working on the subject. It contains a large number of references, many of them to papers written in 1938. It is a pity that several of the chemical formulx are incorrectly printed.

\section{The Extra Pharmacopoeia}

J3y Martindale. Twenty-first edition. In 2 vols. Vol. 2. Pp. xxxvi+1148. (London: Tho Pharmaceutical Press, 1938.) 22s. $6 d$.

THE "Extra Pharmacopoeia" has been produced by the Pharmaceutical Society since the death of Dr. W. H. Martindale in 1933. The twenty-first edition is the first to bo completely produced in this way and it is now completed by the issue of volume 2 , which is considerably larger than the last volume 2 . This volume contains 330 pages of analytical addenda to volume 1; comprehensive information about proprietary medicines, a new section on the nomenclature of organic compounds which contains information not readily available elsewhere ; 70 pages of tests on blood and urine; sections on vitamins, milk, margarine, jam and various other foods; preservatives; 135 pages of clinical notes on various diseases; articles on chemotherapy, radium, X-rays, electrotherapy, and much information about chemical tests of all kinds. The book contains $a$ vast amount of information and numerous references to recent medical literature. It has been brought thoroughly up to date and the revision must have involved much work. It will bo useful not only to pharmacists but also to biochemists, medical men and analysts.

\section{Classic Descriptions of Disease}

With Biographical Sketches of the Authors. By Prof. Ralph H. Major. Second edition. Pp. $\mathrm{xxx}+727$. (Springfield, Ill., and Baltimore, MI.: Charles C. Thomas; London: Baillière, Tindall and Cox, 1939.) $27 s$.

7 HF second edition of this fine volume contains 1 nearly a hundred more pages than the first, which was published in 1932 (see NATure, 131, 895; 1933). In addition to a general revision, new sections have been added on malaria, containing extracts from the works of Hippocrates, Aristophanes, Varro, Celsus, Pliny the Elder, Martial, A. F. A. King and Ronald Ross, and on yellow fever, to the knowledge of which Mathew Carey, Benjamin Rush, Carlos Finlay and Walter Reed, from whose works several passages have been selected, made such valuable contributions.

\section{Miscellany}

\section{The Science of Society}

An Introduction to Sociology. By Dr. J. Rumney. Pp. 125. (London: Gerald Duckworth and Co., Ltd., 1938.) 3s. $6 d$. net.

TN these days, few scientific workers can afford to 1 be indifferent to sociology, whether or not they are convinced as to the possibility of a science of society. Even if they are concerned merely in planning in its narrowest technical sense, planning presupposes some understanding of the structure of society and the intimate interrelation between social life and material techniques, and the inability to realize the importance of a sociological approach lies behind many of the gravest difficulties of our time, such as unemployment, the revolt against democracy, mechanized or commercialized leisure, and blind resentment towards science because the benefits it was expected to bring have either not materialized or largely been missed. In this volume, Dr. Rumnoy indicates for the general reader not only the content of sociology, but also its possibilities as a practical instrument no less than for theoretical purposes.

The sociologist firmly believes that the scientific study of human affairs will ultimately provido a body of knowledgo and principles that will facilitate the control and improvement of social conditions. His first task is to determine the range and structure of human society and of social institutions; the second is to investigate the nature of the interdependence of the structures that function in social life; and the third to establish empirical generalizations, or laws of change and growth in social life, and if possible to interpret them in the light of more ultimate laws. Dr. Rumney does not disguise the difficulties in the methods and technique of social study, and he stresses the importance of objectivity and the elimination of bias, as well as tho absurdity of expecting the methods of social science to conform exactly to thoso of the abstract sciences. This brief account is eminently readable, not only for its avoidance of jargon, but also for the admirable way in which it discusses somo of the biological aspects of sociology, such as the absurd racial claims sometimes advanced to-day, and the biology of war. Dr. Rumney gives a clear but brief account of the limitations no less than the opportunities of social study, and his book can be heartily recommended to the scientific worler.

R. B.

The Consumer-Buyer and the Market

By Jessio V. Coles. Ip. xviii +596. (New York : John Wiley and Sons, Inc. ; London : Chapman and Hall, Ltd., 1938.) 17s. 6d. net.

TP to the time of the great depression in the United States, the average wage-earner there was more concerned with increasing his money income than his real income. During the depression millions of families were forced, in the attempt to maintain customary standards of living on falling incomes, to search for 100 cents' value in every dollar spent. As a result, there has been a steady growth 